\title{
Relative water-level rise in the Flevo lagoon (The Netherlands), 5300-2000 cal. yr BC: an evaluation of new and existing basal peat time-depth data
}

\author{
B. Makaske ${ }^{1,2}$, D.G. Van Smeerdijk ${ }^{3}$, H. Peeters ${ }^{4}$, J.R. Mulder ${ }^{1}$ \& T. Spek ${ }^{1,5}$ \\ 1 Alterra, Wageningen University and Research Centre, P.O. Box 47, \\ 6700 AA Wageningen, The Netherlands \\ ${ }^{2}$ Corresponding author; e-mail: bart.makaske@wur.nl \\ 3 BIAX Consult, Hogendijk 134, 1506 AL Zaandam, The Netherlands \\ 4 National Service for Archaeological Heritage (ROB), P.O. Box 1600, \\ 3800 BP Amersfoort, The Netherlands \\ ${ }_{5}$ Present address: National Service for Archaeological Heritage (ROB), P.O. Box 1600, \\ 3800 BP Amersfoort, The Netherlands
}

Manuscript received: October 2000; accepted: January 2003

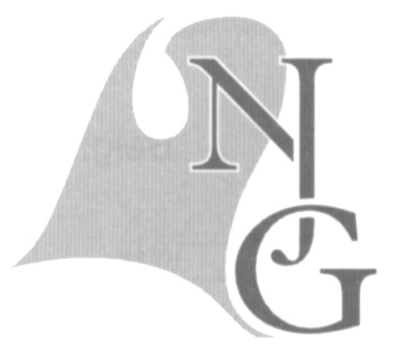

\begin{abstract}
The rise of Holocene (ground)water level as a function of relative sea-level rise has been extensively investigated in the western Netherlands, whereas few studies focused on the Flevo lagoon in the central Netherlands. In this study, all available ${ }^{14} \mathrm{C}$ dates from the base of basal peat overlying the top of compaction-free Pleistocene sand in the former Flevo lagoon were evaluated in order to reconstruct water-level rise for the period $5300-2000 \mathrm{cal}$. yr BC. The present basal peat ${ }^{14} \mathrm{C}$ data set from Flevoland consists of two subsets: (1) the largely new Almere data (41 dates) representing the southern part of the former Flevo lagoon, with 26 dates especially carried out for this study, and (2) the existing Schokland data (21 dates) representing the eastern part of the lagoon. The Schokland area is located about $50 \mathrm{~km}$ from the Almere area. The quality of all basal peat time-depth data was palaeo-ecologically and geologically evaluated, all ${ }^{14} \mathrm{C}$ dates were calibrated to the same standards, and error margins of age and altitude determination were estimated. After plotting the data as error boxes in time-depth graphs, lower limit curves for water-level rise were constructed for both data sets. Comparison with the mean sea-level curve for The Netherlands (Van de Plassche, 1982) suggests that water-level rise in the Almere area between 5300 and 2000 cal. yr BC corresponded closely to the rise in mean sea level. The same holds for the Schokland area for the period 5000-4200 cal. yr BC. For the period 4200-2000 cal. yr BC, however, the Schokland data suggest water-level rise to have been slower than mean sea-level rise, leading to local water levels apparently below mean sea level, which is virtually impossible. Hypothetical explanations for this discrepancy include: errors and uncertainties in mean sea-level and local water-level reconstruction, basin subsidence and temporal differences in intra-coastal tidal damping. The presently available data are inconclusive at this point and Holocene water-level rise in the Flevo lagoon awaits further investigations.
\end{abstract}

Keywords: basal peat bed, ${ }^{14} \mathrm{C}$ dates, water level, sea-level change, tidal amplitude, Flevo lagoon, basin subsidence

\section{Introduction}

The reconstruction of Holocene sea-level rise by radiocarbon dating of basal peat has a long tradition in The Netherlands, with a major part of the research carried out in the western Rhine-Meuse delta (Fig. 1). In this region, the presence of steep Pleistocene aeolian dunes covered by Holocene peat enabled collection of time-depth data in small areas showing the evolution of the local water level in the back-barrier coastal plain, which was principally driven by relative sea-level rise (Jelgersma, 1961; Louwe Kooijmans, 1974; Van de Plassche, 1982, 1995a; Van Dijk et al., 1991; Törnqvist et al., 1998).

A little studied area in this respect is the former Flevo lagoon, which existed north of the RhineMeuse delta (Fig. 1). A study of Holocene water-level evolution in this area (Roeleveld \& Gotjé, 1993), suggests mean water level in the eastern Flevo lagoon between 4200 and 2000 cal. yr BC to have been well below mean sea-level [using the mean sea-level curve of Van de Plassche (1982)], which is virtually impossi- 


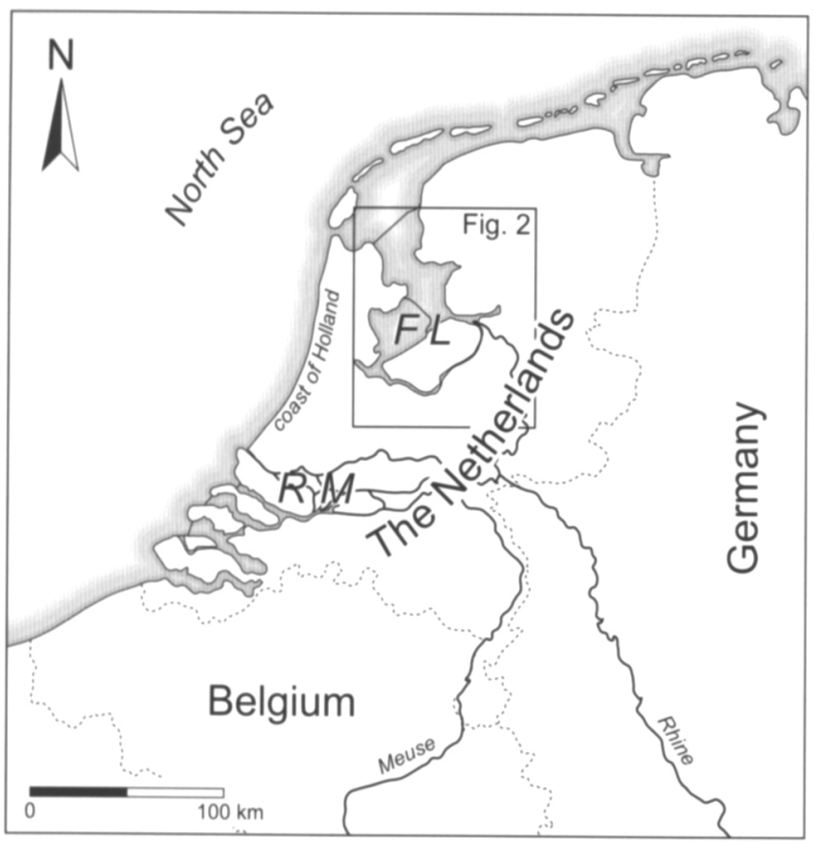

Fig. 1. Map of the Netherlands, showing the locations of the former Flevo lagoon (FL), the Rhine-Meuse delta (RM) and the coast of Holland. Location of Fig. 2 is also shown.

ble. Although instantaneous water level in the backbarrier lagoon may be below mean sea level during a part of the tidal cycle, on the longer term mean water level has to be at or slightly above mean sea level. Until now, this discrepancy is unexplained. The scarcity of other basal peat data from the Flevo lagoon prohibited validation of the curve of Roeleveld \& Gotjé (1993) for the evolution of regional water level.

The evolution of water level is relevant for the study of palaeogeography and prehistoric human occupation of the Flevo lagoon region. Archaeological sites have been discovered at several metres below the present surface and have proven to be rich information sources enabling the study of Stone Age forager behaviour within a palaeo-environmental context (e.g. Hogestijn \& Peeters, 2001). The change from a 'dry' coversand woodland area into a vast peat swamp, which occurred in the major part of the Flevo lagoon region during the Middle and Late Stone Age (8800-2000 cal. yr BC), must have had far-reaching repercussions on the possibilities of land use by prehistoric foragers and early farmers. In order to model these consequences in terms of the function and location of archaeological sites and the quality of archaeological remains, reliable data on water-level evolution and palaeogeography are important. In 1998, the National Service for Archaeological Heritage (ROB) initiated the 'Southern Flevoland Project', which aims at the development of a framework and methodology for assessment of the archaeological potential of Zuidelijk Flevoland (Fig. 2) (Peeters et al., 2002). The present study forms part of this project of which the integrated results will be published later.

For the present study, a large number of new basal peat time-depth data (26 dates) were collected in a study area near Almere in the southern part of the former Flevo lagoon (Figs. 2 and 3), for palaeowaterlevel reconstruction. Additionally, 15 dates are available from near the study area (locations a-f in Fig. 2). These dates are more or less a by-product of various archaeological studies (Van Smeerdijk, 1989; Spek et al., 1997; Gotjé, 2001; Makaske et al., 2002b). Together the Almere data (totalling 41 dates) almost cover the same time interval as the Schokland data (21 dates) used by Roeleveld \& Gotjé (1993) from locations g-k in Fig. 2.

The objectives of this paper are: (1) to present the new data from the Almere area, (2) to reconstruct the evolution of palaeowater-levels in the Almere area, (3) to compare the palaeowater-level reconstructions for the Almere and Schokland areas with each other and with the mean sea-level curve of Van de Plassche (1982).

\section{Holocene geology of Flevoland and the study area near Almere}

All ${ }^{14} \mathrm{C}$ dates discussed in this paper represent basal peat samples from the province of Flevoland, which comprises three areas that were reclaimed from the IJsselmeer (Lake IJssel) between 1937 and 1968: the Noordoostpolder, Oostelijk Flevoland and Zuidelijk Flevoland (Fig. 2). The former saline Zuiderzee was transformed into a freshwater lake (Lake IJssel) by the construction of an enclosure dam in 1932. The Zuiderzee in turn was a successor of the fresh to brackish Flevo lagoon, which existed for a major part of the Holocene until late Subatlantic times (e.g. Zagwijn, 1986).

The top of the Pleistocene substratum in Flevoland consists largely of Weichselian aeolian coversands of the Twente Formation. In addition, sandy fluvial deposits of the Kreftenheye Formation occur in an eastwest trending palaeovalley in the north of Oostelijk Flevoland and in the Noordoostpolder, and Saalian glacial tills of the Drente Formation locally occur in the Noordoostpolder. Overlying Holocene peat and clastic deposits form part of the Westland Formation. The study area where the new basal peat samples were collected is near Almere (Figs 2 and 3). The lithostratigraphic subdivision, used in this paper applies to the study area and is given in Fig. 4.

In the study area, the top of the coversand forms a northward sloping subsurface with considerable relief (Menke et al., 1998). Buried coversand ridges may 


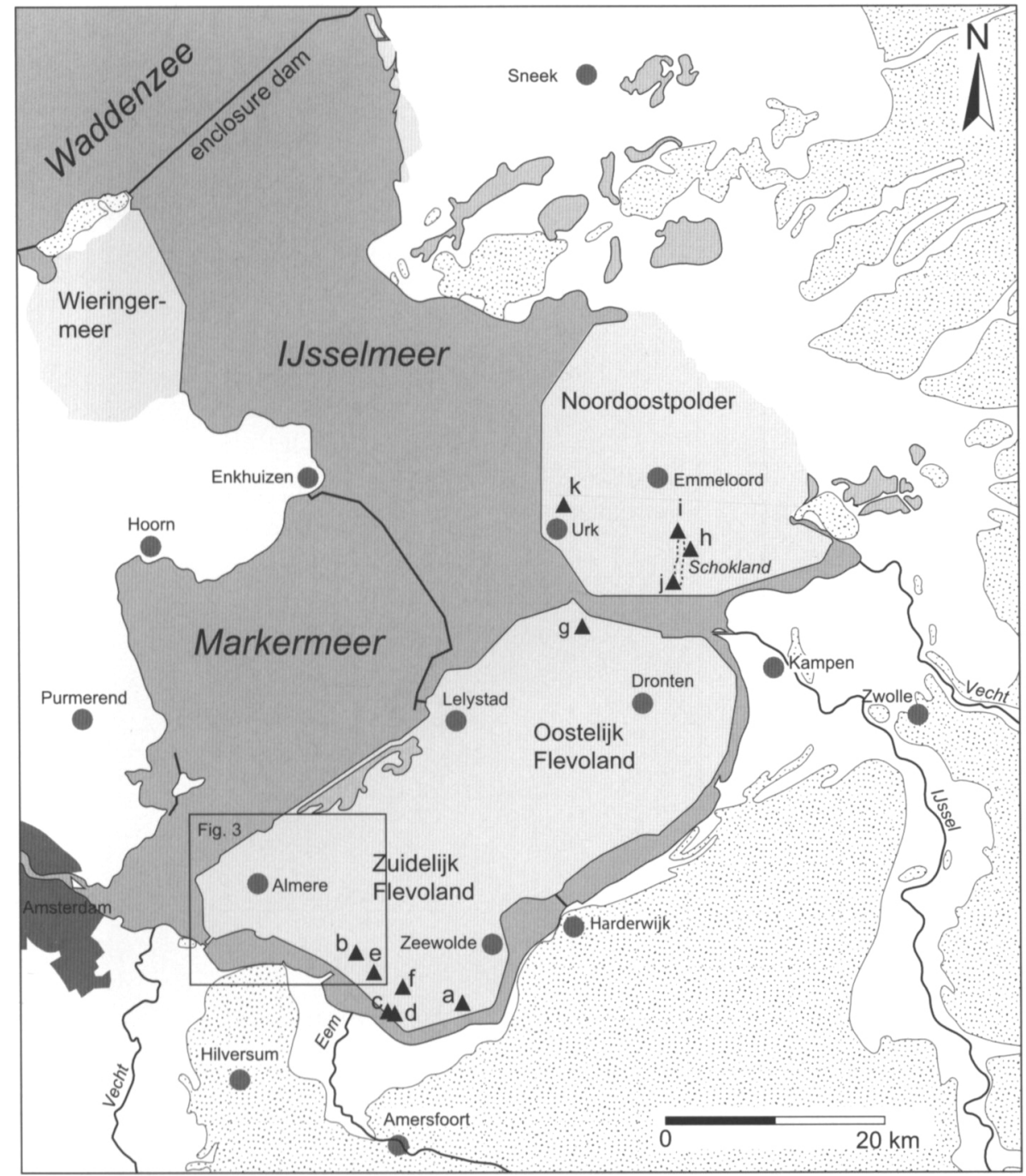

Fig. 2. Map of Flevoland Noordoostpolder, Oostelijk Flevoland and Zuidelijk Flevoland) and the IJsselmeer region, showing sampling locations of ${ }^{14} \mathrm{C}$-dated basal peat samples from other studies, and the location of Fig. 3.

Legend

$\begin{array}{ll}\square & \text { water } \\ \square & \text { outcropping Pleistocene deposits } \\ \square & \text { land reclaimed since } 1927 \mathrm{AD} \\ & \text { major town } \\ & \text { river }\end{array}$

have steep flanks and typically rise about $2 \mathrm{~m}$ above the surrounding Pleistocene surface, whereas some (parabolic) dune complexes reach a height of 4 to $5 \mathrm{~m}$. Small rivers have incised 2 to $3 \mathrm{~m}$ into the coversand plain (Fig. 5). This relief resulted in large spatial and temporal differences in onset of inundation during the Holocene transgression. Complex soils developed in the coversand in the course of the Holocene, prior to inundation (e.g. Spek et al., 1997; Makaske et al., 2002b).

Formation of the Basal Peat (Fig. 4) started when groundwater level reached the surface of the coversand. Subsequently, as groundwater level continued to rise, a typical Holocene coastal sedimentary sequence developed, consisting of intercalated organic and clastic layers (Menke et al., 1998). Clastic tidal deposits of Atlantic age (Older Tidal Deposits; Fig. 4) in many places erosively overlie the Basal Peat. Locally, tidal channels have scoured deeply into the Pleistocene coversand. At a later stage, mainly during the Subboreal, the Holland Peat (Fig. 4) formed on top of the tidal deposits. Near the margins of the Flevo lagoon, Holland Peat grades into Basal Peat that continued to form on the submerging Pleistocene sand. During late Subboreal and early Subatlantic times, large freshwater lakes gradually expanded at the expense of the peat area and much of the Holland Peat and Basal Peat was reworked and deposited on lake bottoms (Flevomeer Deposits; Fig. 4). Erosion in these lakes was less rigorous than in the preceding 


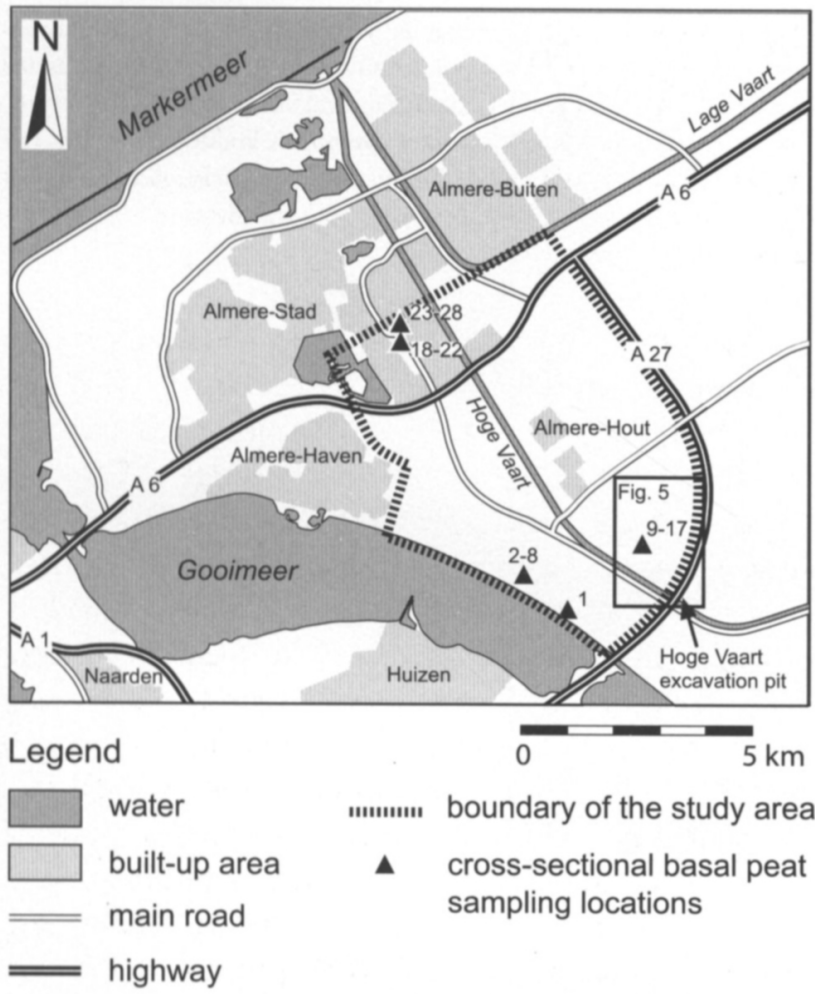

Fig. 3. Map of the study area near Almere, showing sampling locations of ${ }^{14} \mathrm{C}$-dated basal peat samples from this study and the location of the Hoge Vaart archaeological excavation pit. Numbers of sampling locations correspond to sample numbers given in Table 1 and Figs. 6, 7 and 8. Location of Fig. 5 is also shown.

tidal channel system, and therefore reworked peat may presently overlie coversand with a more or less intact soil profile. In middle and late Subatlantic times, marine clastic deposition dominated (Almere, Zuiderzee and IJsselmeer Deposits; Fig. 4). In many places, the base of the Almere Deposits truncates older deposits. Fig. 6 shows a characteristic Holocene sequence of lithostratigraphic units from the study area, in which the Holland Peat has been totally eroded and replaced by Flevomeer Deposits.

\section{Data collection}

Data on the occurrence of basal peat and the depth of the Pleistocene coversand in the study area near Almere (Fig. 3), were kindly supplied by the Directorate-General for Public Works and Water Management (Rijkswaterstaat-RIZA, Lelystad) in the form of unpublished geological maps and borehole descriptions. Although these data provided a useful framework for the present study, 135 additional borings had to be carried out to select suitable locations for sampling basal peat for ${ }^{14} \mathrm{C}$ dating. Locations featuring a slope in the Pleistocene subsurface were preferred, to avoid as much as possible situations where local palaeowater-level was raised relative to regional palaeowater-level due to poor drainage. The palaeore-

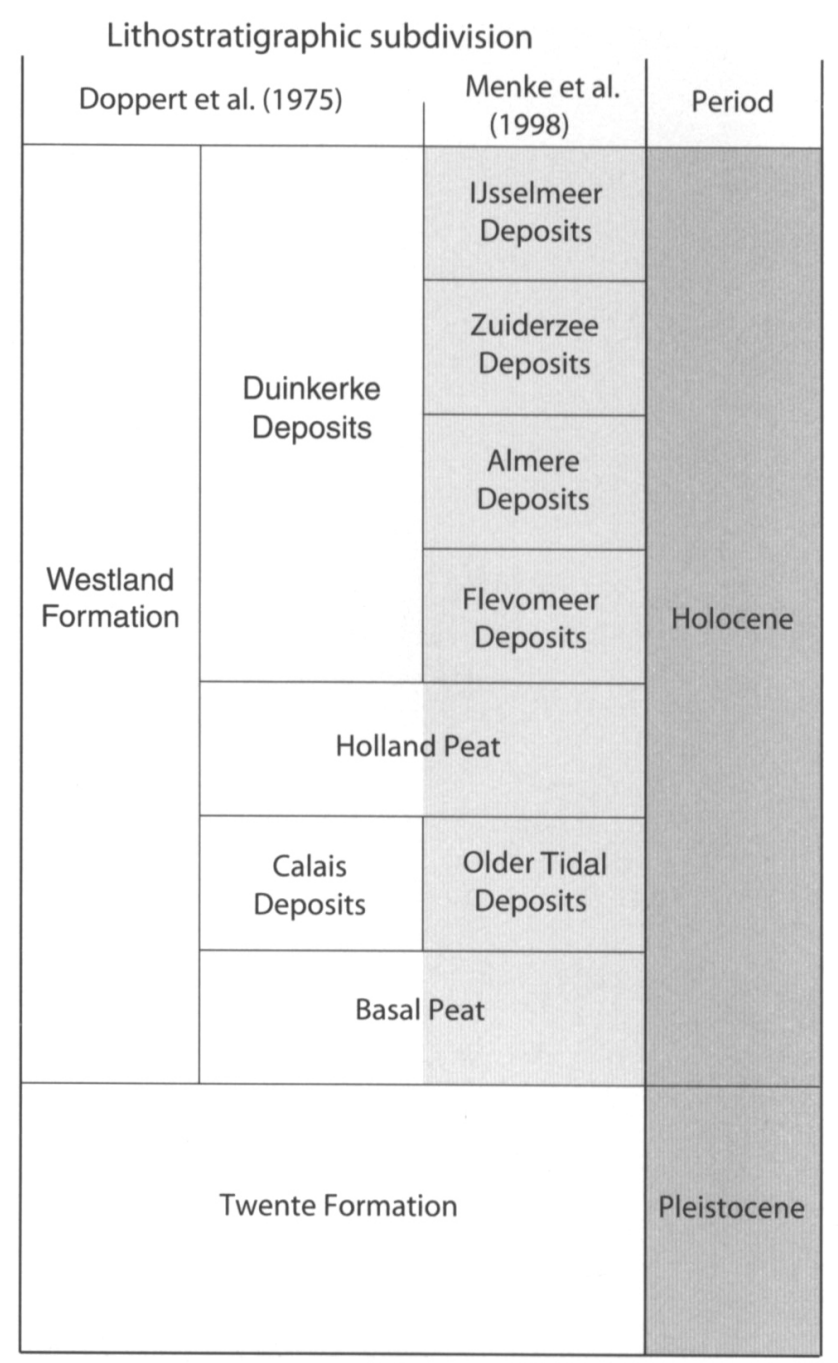

Fig. 4. Late-Pleistocene and Holocene lithostratigraphic units in the Almere area according to the subdivision of Doppert et al. (1975) with additions of Menke et al. (1998).

lief of the coversand landscape was too limited to allow collection of a wide range of time-depth data at one location. In order to cover the maximum range possible within the study area, sampling was carried out at five different (cross-sectional) sampling locations (Fig. 3). It can not be excluded that sub-regional differences in palaeowater-level existed between these locations.

At each sampling location, a borehole cross-section gives a detailed picture of the subsurface topography and local stratigraphy (e.g. Fig. 7). Borehole locations in the cross-sections were levelled relative to Dutch O.D. (= NAP). Most cross-sections were oriented such that basal peat could be sampled on the flank of coversand ridges. The basal peat was always critically examined since beds of reworked peat are common in this area. It was also important to avoid sampling of early Holocene soil material from the A-horizon underlying basal peat, since this material would yield 'too old' ages unrelated to drowning of the coversand 


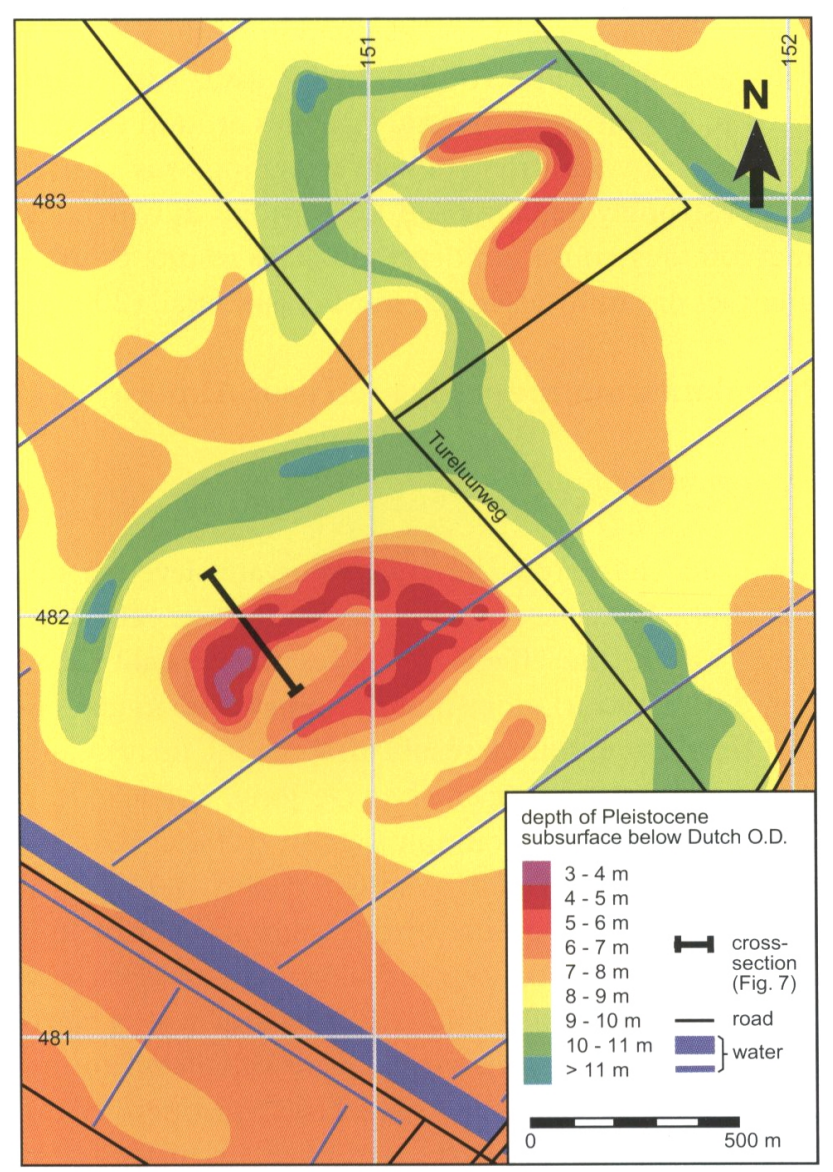

NNW SSE
Fig. 5. Contour map showing the morphology of the Pleistocene subsurface near one of the studied cross-sections in the study area (see Fig. 3 for location). Two parabolic dune complexes stand out, as well as a winding river course. Based on Heidemij (1993) and unpublished data of the Directorate-General for Public Works and Water Management (Rijkswaterstaat-RIZA, Lelystad). Map co-ordinates according to Dutch co-ordinate system.

surface. However, a sharp boundary between the Ahorizon and the overlying basal peat could not always be identified in the field. Radiocarbon samples of basal peat were collected using a gouge $(\varnothing 6 \mathrm{~cm})$. Usually, 40 to $100 \mathrm{~cm}$ long sediment cores, including the sand-peat contact, were packed in plastic boxes $(4 \times 5 \times 39.5 \mathrm{~cm})$ or PVC-tubes and taken to the laboratory. There the core was cut into $1-\mathrm{cm}$-thick slices from each of which two small (around $1 \mathrm{~cm}^{3}$ ) bulk samples were reserved for ${ }^{14} \mathrm{C}$ dating (in case no terrestrial macrofossils were found, see below) and pollen analysis. The remainder of the material of each slice was treated with $5 \% \mathrm{KOH}$ for 12 hours at room temperature prior to sieving over a $170 \mu \mathrm{m}$ screen. Volumetric sand content $(<170 \mu \mathrm{m}$ and $>170 \mu \mathrm{m}$ fractions) was determined visually after sieving. A sharp decrease in sand content was considered indicative for the transition from coversand to basal peat. From the slice directly above the transition level,

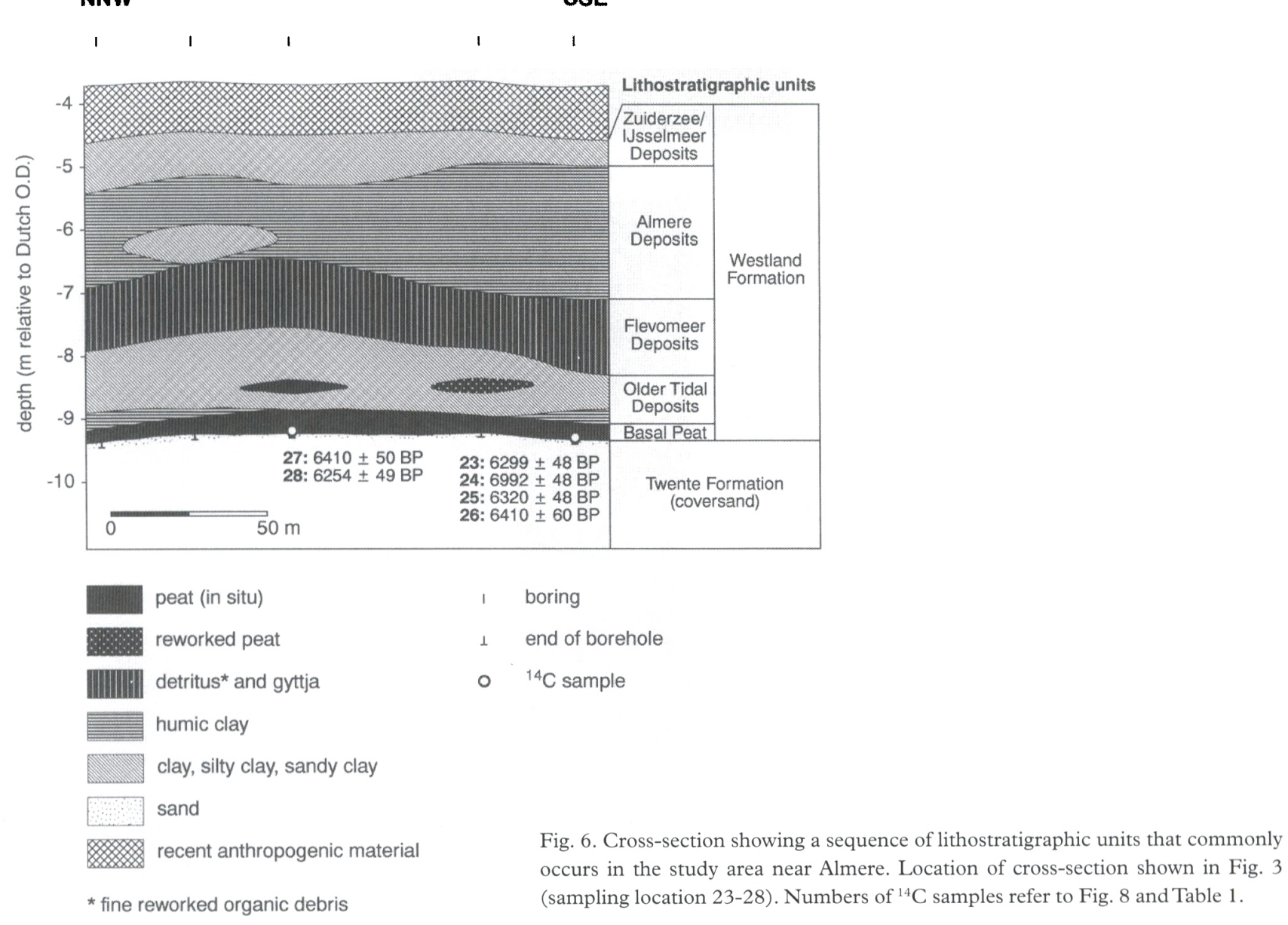


material was selected for Accelerator Mass Spectrometry (AMS) ${ }^{14} \mathrm{C}$ dating. Volumetric sand content of this slice was always below $10 \%$ and usually below 5\%. Preferentially, terrestrial macrofossils (such as fruits and nuts) were picked for dating, using a binocular microscope. Törnqvist et al. (1992) showed that dating of selected terrestrial macrofossils yields more accurate results than the dating of bulk peat samples. However, many of our samples consisted of strongly decomposed peat containing too few terrestrial macrofossils for AMS dating, forcing us to use bulk peat samples for dating. Radiocarbon ages obtained from such bulk peat samples may be affected by a number of potential error sources (e.g. Mook \& Streurman, 1983), most importantly: (1) allochthonous organic matter, (2) infiltrated younger carbon (e.g. fulvic and humic acids), and (3) roots from higher levels. Thus, erroneously young or old ages may arise from bulk peat samples and caution should be used in interpreting the dating results.

In some cases, we selected sub-samples of different materials (such as wood, charcoal, and Phragmites) from the same slice as bulk samples for dating, to evaluate the effects of these materials on the ages obtained from bulk samples. In most cases the ${ }^{14} \mathrm{C}$ ages of subsamples and bulk samples were in close agreement. In three cases there were significant differences, which will be discussed in the next section. Twenty-eight samples were submitted to the Van de Graaff Laboratory (Utrecht University) for ${ }^{14} \mathrm{C}$ analysis, two of which turned out to be too small to be dated (Table 1).
For a palaeo-ecological evaluation of the ${ }^{14} \mathrm{C}$ samples, a complete macrofossil analysis was carried out of 3- to 15-cm-thick organic intervals around the dated levels. In addition, pollen screening was carried out of strongly decomposed ${ }^{14} \mathrm{C}$ samples in which few macrofossils could be identified. The results of these analyses are fully described in Makaske et al. (2002a).

\section{New data from the study area near Almere}

\section{Data presentation}

We used calibrated ${ }^{14} \mathrm{C}$ ages for water-level reconstruction. Water-level curves based on uncalibrated ages include the effect of wiggles in the calibration curve (due to variations in atmospheric ${ }^{14} \mathrm{C}$ in geological time), which may result in apparent fluctuations in the rate of water-level rise (De Jong, 1981, p. 87). The Groningen calibration program (version CAL25) was used for calibration (Van der Plicht, 1993), while the degree of smoothing of the calibration curve followed recommendations of Törnquist \& Bierkens (1994) (see Table 1 for details). For four sets of related ${ }^{14} \mathrm{C}$ dates, weighted means were calculated to improve precision (Table 2), which was justified by the close agreement of the ${ }^{14} \mathrm{C}$ ages of different sub-samples and bulk samples from exactly the same altitude and location. Three dates have a large standard deviation due to very low amounts of carbon available for dating (samples 1, 4 and 17); all other dates have low standard deviations (Table 1).

\section{NW}

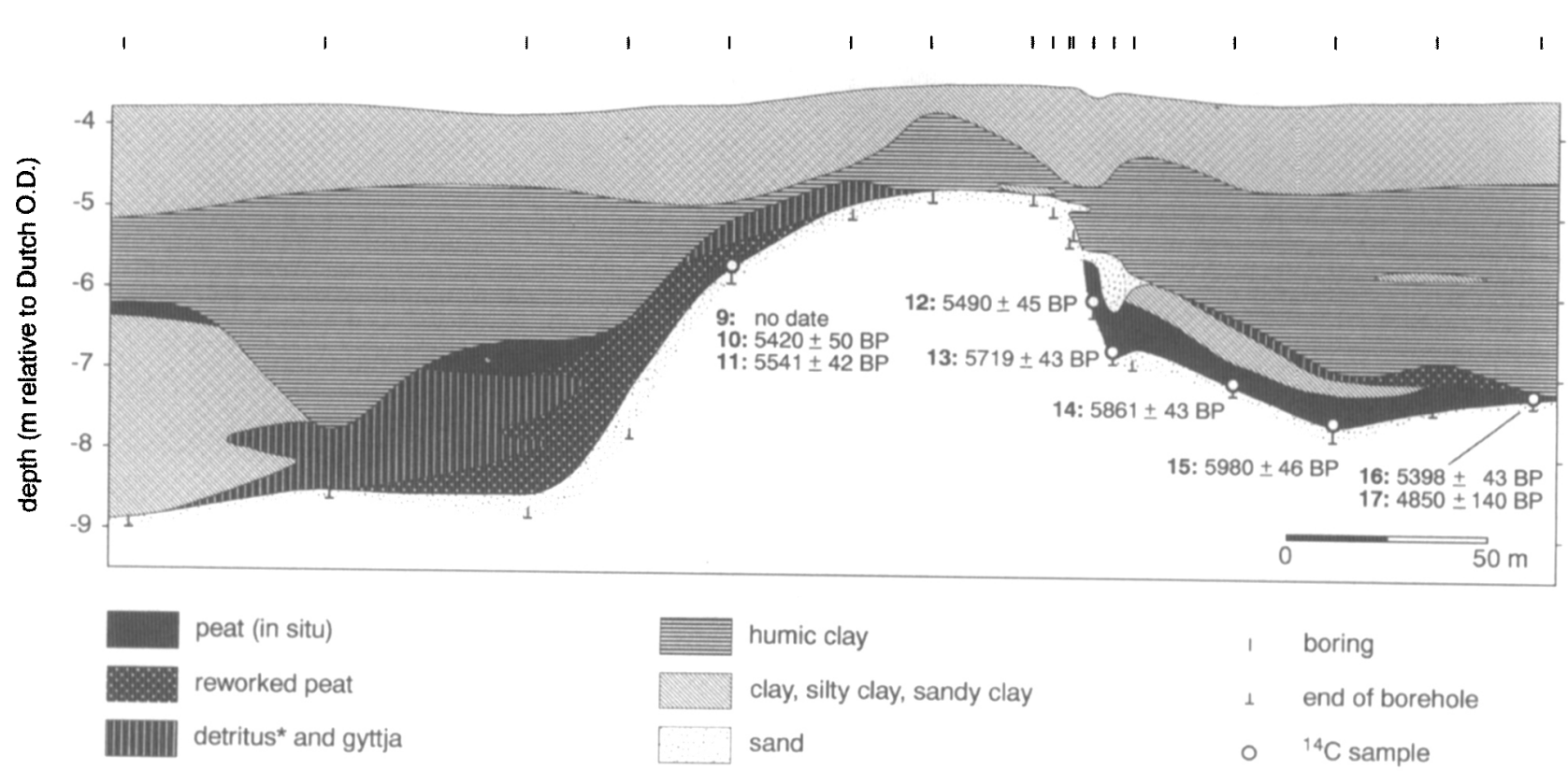

* fine reworked organic debris

Fig. 7. Cross-section showing detailed stratigraphy and sampling locations across the north-western limb of the parabolic dune complex shown in the middle of Figure 5. Numbers of ${ }^{14} \mathrm{C}$ sampling locations refer to Fig. 8 and Table 1. 


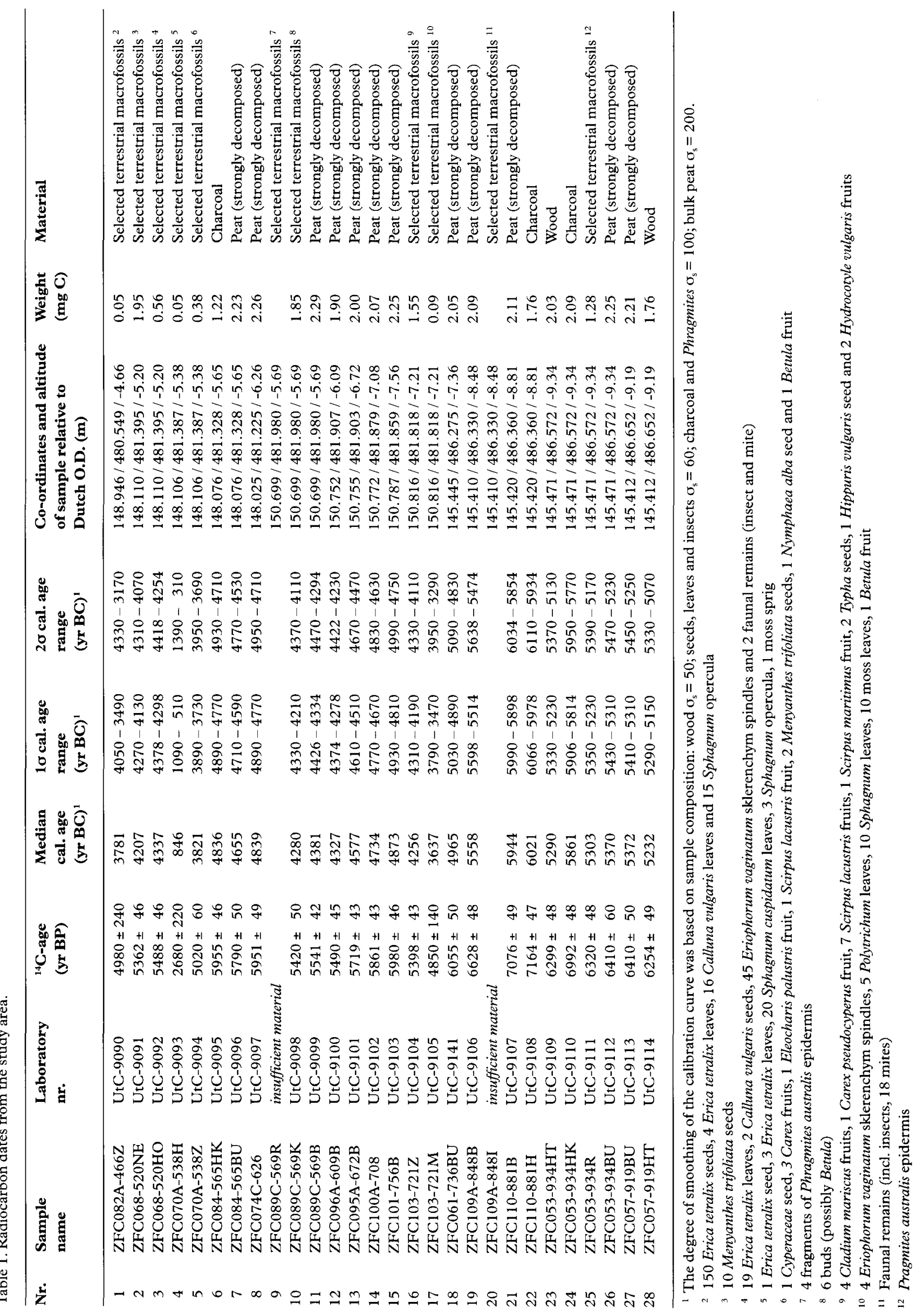


The time-depth data were plotted as error boxes indicating estimated uncertainty ranges in time and depth (Fig. 8). Uncertainty ranges in time are represented by the $1 \sigma$ and $2 \sigma$-confidence intervals $(68.3$ and $95.4 \%$ statistical confidence, respectively). The uncertainty range in depth consists of two components. Firstly, a vertical error of $\pm 5 \mathrm{~cm}$ is estimated for the sampling method and altitude measurement. Secondly, with respect to the indicative value of the dated material for local palaeowater-level, Van de Plassche \& Roep (1989), Kiden (1995) and Törnqvist et al. (1998) are followed, assuming that peat growth will take place within $\pm 10 \mathrm{~cm}$ of the local water level. In summary, the total vertical uncertainty for local water level is estimated to be $\pm 15 \mathrm{~cm}$, which is accounted for in the error boxes. In Fig. 8, the new data plot as a band with a diffuse margin on the left and, apart from three outliers that appear much too young (boxes 4, 16 and 17), with a margin on the right that is better defined. To explain the distribution of the error boxes, a geological and palaeo-ecological evalua- tion of the data was carried out. Four categories of dated material could be identified and will be described below.

\section{Dates of wood-reed peat}

Boxes 23/25/26 and 27/28 represent samples that were dominated by Phragmites and (mostly unidentifiable) wood remains. As a check on the accuracy of the dates obtained from this material, subsamples of wood (date 23) and Phragmites (date 25) from the same location (Fig. 6) were dated separately. Radiocarbon ages were highly consistent and in agreement with a date of a bulk peat subsample from the same location (date 26). Separate dating of subsamples of wood (date 28) and bulk peat (date 27) from a neighbouring location (Fig. 6) yielded comparable results. The consistency of the dating results obtained from bulk peat and different constituents of the peat renders rejuvenation by roots from higher levels unlikely. Early (oligotrophic) peat-growth unrelated to regional

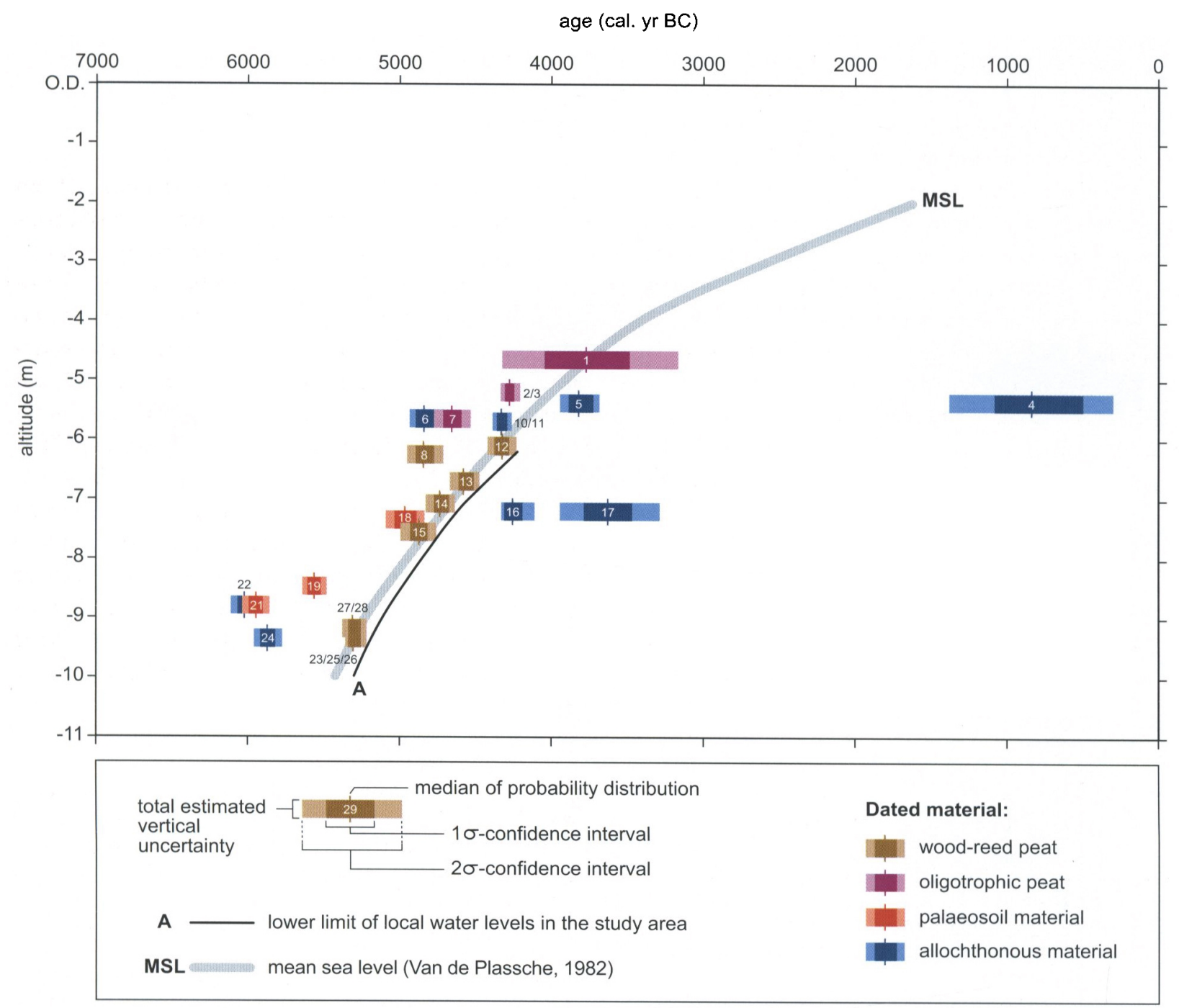

Fig. 8. Reconstruction of water-level rise based on the data from the study area near Almere. Numbers of error boxes refer to Table 1. 
water-level rise at this location, which is characterized by a virtually flat coversand surface, also seems unlikely, since Phragmites indicates eutrophic conditions. In addition, the association with wood suggests that peat formation took place near (ground)water level.

Boxes 12 through 14 represent samples with a comparable wood-reed composition collected on the inward slope of a buried parabolic dune (Figs. 5 and 7). Box 15 represents a sample from the lowest part of the central depression of the parabolic dune. This sample also consisted of unidentifiable wood remains, however, remains of Phragmites were lacking. Abundant Betula pollen in this sample suggest that Betula was locally present. This could indicate that initially mesotrophic rather than eutrophic conditions existed at this location. Box 8 also represents a sample taken from the foot of a coversand ridge, but unlike sample 15, sample 8 contained Phragmites next to wood remains.

\section{Dates of oligotrophic peat}

Boxes 1, 2/3 and 7 are believed to represent oligotrophic peat that developed independent of the regional water level. Sample 1 was taken from a $40-\mathrm{cm}-$ thick peat bed capping the top of a buried coversand ridge and contains abundant Sphagnum, Calluna vulgaris and Erica tetralix macrofossils (Table 1). Samples 2, 3 and 7 originate from a $15-25 \mathrm{~cm}$ thick peat bed draping the south-western flank of the same coversand ridge. Macrofossil analysis of the peat yielded ambiguous results, with indicators of eutrophic/ mesotrophic as well as oligotrophic environments. In case of samples 2 and 3, Menyanthes trifoliata (sample 2), which is usually indicative of an eutrophic/ mesotrophic shallow open water environment, was separately dated from remains of oligotrophic species like Erica tetralix and Calluna vulgaris (sample 3) (Table 2). Both samples, originating from the same level in one core, yielded the same ${ }^{14} \mathrm{C}$ age, suggesting that the different species lived concurrently at this location. Pollen screening of the peat bed in various cores indicated upward increase of Sphagnum and Er- icales microfossils. Conditions of peat formation on the flank of the coversand ridge probably changed from mesotrophic to oligotrophic, indicating decreasing influence of regional water-level development on local hydrology.

\section{Dates of palaeosoil material}

Boxes 18, 19 and 21 represent a very thin peat bed $(\leq 11 \mathrm{~cm})$ on the flank of a low $(1.5 \mathrm{~m})$ buried coversand ridge. Macrofossil analysis of the material yielded much charcoal, wood remains and the soil fungus Cenococcum geophilum. Macrofossils of eutrophic peatforming taxa are poorly represented and abundant charcoal suggests dry topsoil conditions. Pollen screening indicated local presence of Ericales. Ericales pollen is also abundant in de sandy subsoil. These data lead to the interpretation that samples 18 , 19 and 21 include material from the top of the palaeosoil in the coversand and therefore represent the time before peat formation. Van de Plassche (1982, p. 58) and Spek et al. (1997, table 4) showed that erroneous dating of old soil carbon may offset data points by 500 to $1000{ }^{14} \mathrm{C}$-years.

\section{Dates of allochthonous material}

Boxes 4 and 5 in Fig. 8 represent subsamples from exactly the same level within one core. Macrobotanical analysis revealed a remarkable peat composition at this level, with remains of oligotrophic and mesotrophic/eutrophic species occurring mixed. Boxes 16 and 17 represent a similar situation. As a check, it was decided to separately date the remains of the different plant communities in both cases (Table 1). Radiocarbon ages of the different macrofossil subsets differ considerably. The most likely cause of the differences is that the dates represent later deposited reworked organic material that replaces locally eroded basal peat. Reworked organic material, which can easily be mistaken for basal peat in a narrow core, usually covers a wide range of ${ }^{14} \mathrm{C}$ ages. The geological context of samples 16 and 17 favours this interpretation: the

Table 2 . Weighted means for four sets of related radiocarbon dates.

\begin{tabular}{|c|c|c|c|c|c|c|}
\hline Nr. & $\begin{array}{l}\text { Laboratory } \\
\text { nrs. }\end{array}$ & $\begin{array}{l}{ }^{14} \mathrm{C} \text {-ages } \\
\text { (yr BP) }\end{array}$ & $\begin{array}{l}\text { Weighted } \\
\text { mean }{ }^{14} \mathrm{C} \text {-age } \\
(\text { yr BP) }\end{array}$ & $\begin{array}{l}\text { Median } \\
\text { cal. age } \\
\text { (yr BC) }\end{array}$ & $\begin{array}{l}1 \sigma \mathrm{cal} . \text { age } \\
\text { range } \\
(\mathrm{yr} \mathrm{BC})\end{array}$ & $\begin{array}{l}2 \sigma \text { cal. age } \\
\text { range } \\
(\mathrm{yr} \mathrm{BC})\end{array}$ \\
\hline $2 / 3$ & UtC-9091 / UtC-9092 & $5362 \pm 46 / 5488 \pm 46$ & $5425 \pm 33$ & 4282 & $4314-4250$ & $4342-4210$ \\
\hline $10 / 11$ & UtC-9098 / UtC-9099 & $5420 \pm 50 / 5541 \pm 42$ & $5491 \pm 32$ & 4329 & $4362-4294$ & $4394-4258$ \\
\hline \multirow[t]{2}{*}{$23 / 25 / 26$} & UtC-9109/UtC-9111/ & $6299 \pm 48 / 6320 \pm 48 /$ & & & & \\
\hline & UtC-9112 & $6410 \pm 60$ & $6334 \pm 30$ & 5297 & $5330-5250$ & $5350-5210$ \\
\hline $27 / 28$ & UtC-9113 / UtC-9114 & $6410 \pm 50 / 6254 \pm 49$ & $6330 \pm 35$ & 5293 & $5330-5250$ & $5370-5210$ \\
\hline
\end{tabular}


thin peat bed from which the samples originate could well represent a basal organic lag deposit associated with the thick overlying clastic sequence (Fig. 7). For comparable reasons the geological context of samples 9, 10 and 11 in Fig. 7 is suspect. The basal peat on the north-western flank of the dune has suffered severe erosion followed by redeposition, resulting in a thick bed of reworked peat. It is doubtful if the location of samples 9,10 and 11 has escaped erosion, as was initally believed during coring. The samples could represent a large, displaced block of peat, which would fit with the close agreement in ${ }^{14} \mathrm{C}$ age of the samples 10 and 11 .

A different type of allochthonous material is charcoal. The charcoal subsamples in our study (boxes 6 , 22 and 24) yielded older ages than the surrounding peat (boxes 7,21 and 23/25/26, respectively), although differences are modest in two cases. The dated charcoal is interpreted as allochthonous and probably relates to prehistoric human activities on nearby coversand ridges (e.g. Hogestijn \& Peeters, 2001).

\section{Curve A}

Our wood-reed peat data indicate a succession of local water levels (Fig. 8) that approximates the development of mean sea level as reconstructed by Van de Plassche (1982). The mean sea-level curve fits through the middle of error boxes 12 through 15 and $23 / 25 / 26$ and $27 / 28$. It seems that these boxes indicate local water levels that corresponded to regional water level in the Almere area, which in turn was closely adjusted to mean sea level. 'Regional water level' is defined here as mean water level in an (extensive) open water environment, unaffected by local phenomena such as hindered drainage of rain or river water, or groundwater seepage. Especially along the margins of the Flevo lagoon, gradients in water level due to these factors are likely to have existed. 'Local water level', defined as mean water level at one (sampling) location, may therefore have been above regional water level but cannot have been below it. Curve A in Fig. 8 represents a lower limit of local water levels in the Almere area, taking into account the $95.4 \%$ statistical confidence range in age and the uncertainty in altitude. A general upper limit is poorly defined by nature, because it is not determined by a regional control. For archaeological purposes, a lower limit curve is most useful, since it indicates after which point of time prehistoric occupation at a certain level can be excluded with reasonable certainty.

\section{Additional data from the Almere area}

\section{Data presentation}

Some other data from various locations in the neighbourhood of the study area are available for comparison. After calibration of the original data according to the same standards as our own data, we estimated the total vertical uncertainty for each time-depth point from descriptions of dated material and sampling conditions. In general, vertical uncertainty was composed of the same components as described above for our data $( \pm 5 \mathrm{~cm}$ for sampling method and altitude measurement, $\pm 10 \mathrm{~cm}$ for the uncertainty in the relationship between water level and level of peat formation). For samples thicker than $1 \mathrm{~cm}$, sample thickness was added to vertical uncertainty. For samples not taken directly above the sand-peat contact, an extra upward range of twice the distance between the sand-peat contact and the sample was added to vertical uncertainty, to account for compaction after peat formation (e.g. Roeleveld \& Gotjé, 1993, p. 77). The resulting error boxes were plotted in Fig. 9.

\section{Data quality}

Error box 1, which plots on the MSL-curve, represents a conventional ${ }^{14} \mathrm{C}$ date of bulk Alnus peat directly on top of a coversand palaeosoil profile in an archaeological excavation pit (Van Smeerdijk, 1989), about $10 \mathrm{~km}$ south-east from the present study area (Fig. 2). Altitude of the peat sample was determined less precisely than for the other samples discussed, with an estimated accuracy of $\pm 15 \mathrm{~cm}$ (Van Smeerdijk, 1989). Palaeo-ecological conditions of $A l$ nus peat formation were investigated by macrofossil and pollen analysis.

Error boxes 2 through 9 represent AMS dates from the Hoge Vaart archaeological excavation pit (Figs. 2 and 3). They generally plot somewhat above curve A and the MSL-curve. Error boxes $2 / 3$ and $4 / 5$ relate to dates of Phragmites peat, overlying the highest part of the coversand ridge that was exposed in the Hoge Vaart pit (Spek et al., 1999). Sample selection was supported by extensive pedological, palaeo-ecological and micromorphological analysis of the exposed profile. The dated levels may have been well below local water level at the time of peat formation, since Phragmites peat may form down to $2.0 \mathrm{~m}$ below the water table. For the error box, we took the upward uncertainty of $30 \mathrm{~cm}$, suggested by Spek et al. (1999, pp. 81-82) for these samples, based on palaeo-ecological considerations. Error boxes 6 and 7 relate to ${ }^{14} \mathrm{C}$ dates of Quercus roots in the coversand that had completely 
decayed above a sharply defined level (Spek et al., 1999). This level is considered to represent the lowest limit of groundwater-level fluctuation at the time the oak tree drowned. The age of the roots at the time of drowning causes the boxes to be offset somewhat towards an older age in Fig. 9, a few hundred years at the most. Local mean groundwater level will have been several decimetres above the level indicated and therefore we included $20 \mathrm{~cm}$ upward uncertainty in altitude in the error boxes, in addition to $\pm 5 \mathrm{~cm}$ for sampling method and altitude measurement. Error boxes 8 and 9 represent two levels in a core extracted from the pit, with the lowest sample taken directly above the sandy substratum and the upper sample about $18 \mathrm{~cm}$ higher. The sandy substratum probably belongs to the flank of a buried coversand ridge. Sampled material was described (partly) as fine reworked organic debris ('detritus'). Deposition in shallow wa- ter and local origin of the dated wood and bud fragments was suggested based on macrofossil and pollen data (Gotjé, 2001).

Error boxes 10 through 15 represent basal peat from four high-quality undisturbed cores $(\varnothing 66 \mathrm{~mm}$ ) from various locations south-east of the study area (Fig. 2), extracted with a Begemann continuous soil sampler (Makaske et al., 2002b). Error box 10 stands for an AMS date of macrofossils selected from in situ peat covering the top of a buried coversand ridge. Macrobotanical analysis of the peat yielded abundant Alnus wood fragments. Error boxes 11 and 12 represent two basal peat samples from the same core. Box 11 relates to a conventional date of Alnus wood, whereas box 12 reflects an AMS date of selected macrofossils, predominantly Betula remains. Geological inconsistency of the dating results (the deeper sample yielding the youngest date) suggests that basal

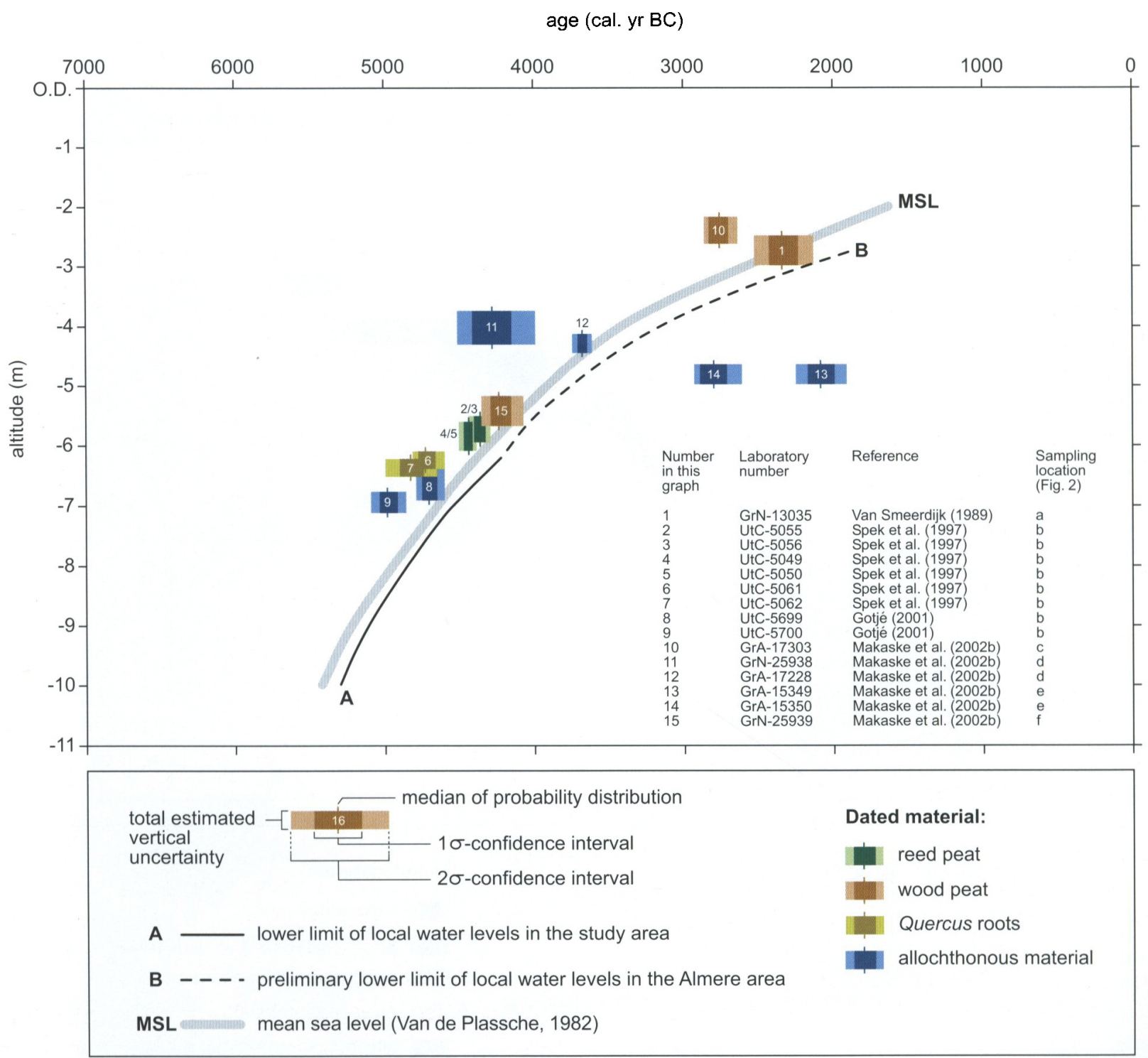

Fig. 9. Preliminary reconstruction of water-level rise in the Almere area for the period 4200-2000 cal. yr BC, based on additional data from Van Smeerdijk (1989), Spek et al. (1997), Gotjé (2001) and Makaske et al. (2002b). 
peat at this location has been reworked. The results of micromorphological analysis favour this interpretation. Error boxes 13 and 14 probably represent a case analogous to described above for boxes 4 and 5, and 16 and 17 in Fig. 8, with different botanical fractions from the same sample yielding different AMS dating results pointing to reworked material. Error box 15 relates to a conventional date of Salix wood resting on a gentle slope of the coversand surface. Macrofossil and micromorphological analysis indicate a context of in situ Salix/Alnus peat for this sample.

\section{Curve B}

The additional data suggest a continuation of curve A slightly below the MSL-curve for the period 42002000 cal. yr BC. This tentative curve B is stippled since it relies on few data (Fig. 9). The data from the Hoge Vaart site plot relatively high, which could indicate that local (ground)water levels at this site were elevated relative to regional water level during the period 5000-4300 yr BC. This may be due to supply of surface water by an old course of the Eem River (Fig. 2) in combination with poorly drained, loamy coversand in the shallow subsurface (Spek et al., 1997). Likewise, error boxes 10 (Fig. 9) and 8 (Fig. 8) may also reflect raised local water levels.

\section{Data from the Schokland area}

\section{Data quality and presentation}

To evaluate the consistency of water levels in the Flevo lagoon, the Almere data are compared to data from Schokland and surroundings in the eastern part of the Flevo lagoon (Fig. 2). To enable a proper comparison, we treated the ${ }^{14} \mathrm{C}$ dates from this area (Ente et al., 1986; Roeleveld \& Gotjé, 1993, App. B) in the same way as our own data, which involved calibration and estimation of total vertical uncertainty. The data

age (cal. yr BC)
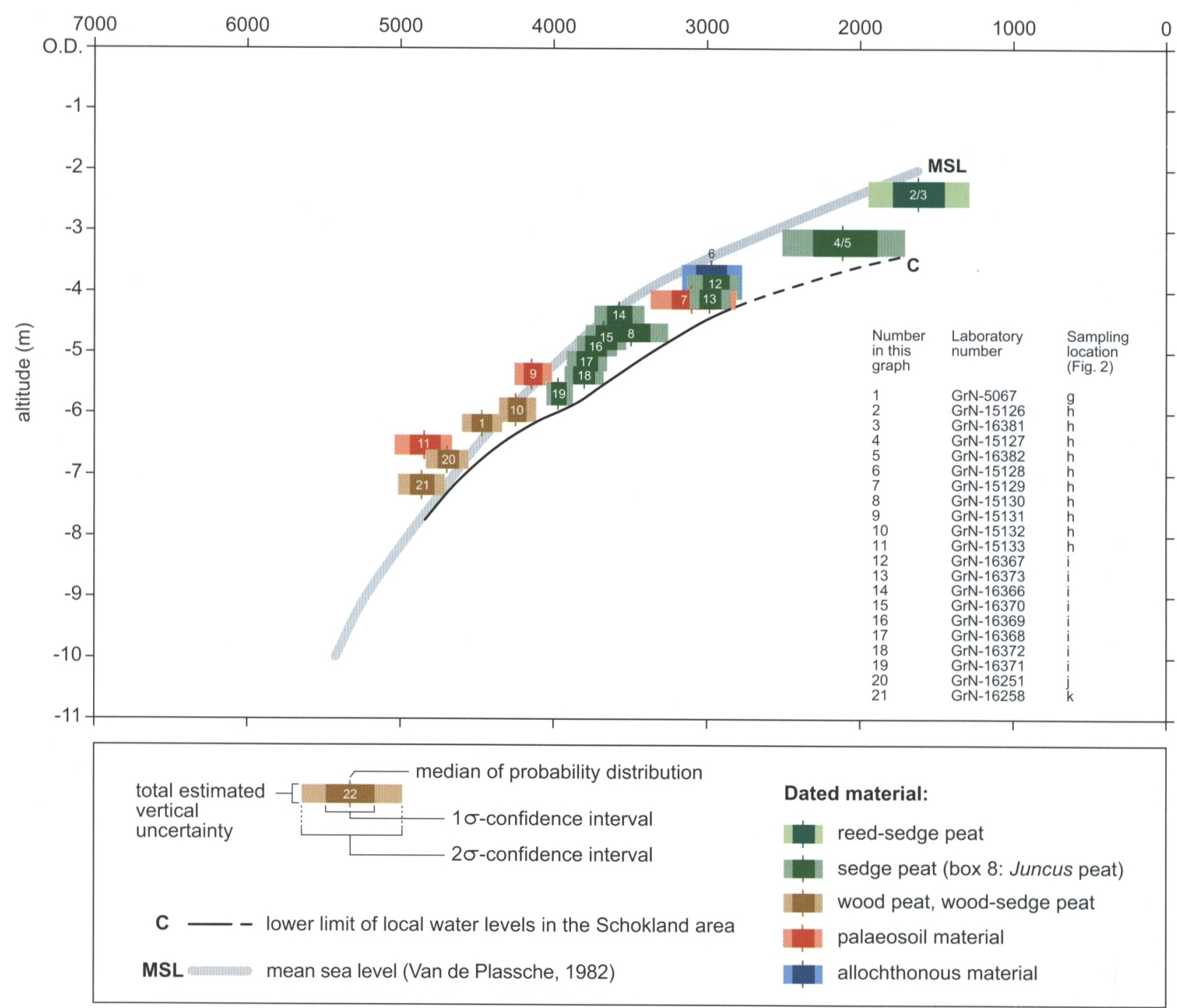

Fig. 10. Reconstruction of water-level rise based on data collected by Ente et al. (1986) and Roeleveld \& Gotje (1993) in the Schokland area. 


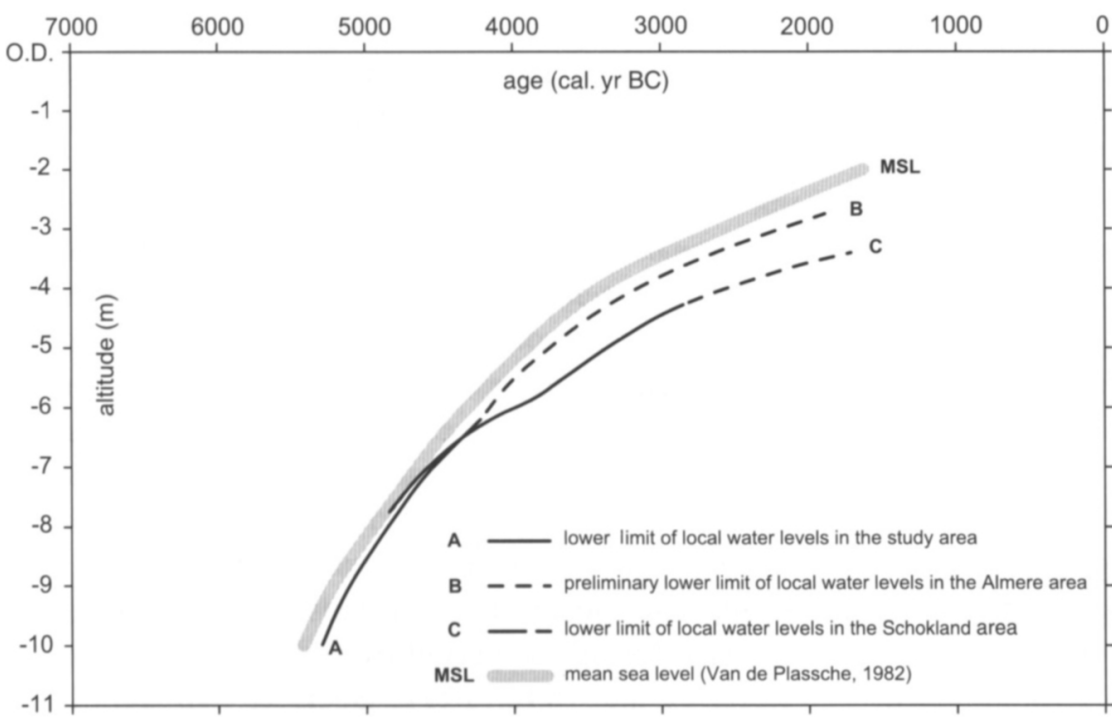

Fig. 11. Summary graph of curves discussed in this paper.

consist of conventional dates of bulk samples of wood peat and Carex peat (frequently comprising Betula remains), mostly sampled from steep flanks of buried Pleistocene dunes. Unlike wood peat, Carex peat may form down to several decimetres below the water table. However, the association with Betula may limit this range. For this reason (and considering additional palaeobotanical data) Roeleveld \& Gotjé (1993, p. 78 ) assumed the sampled basal peat to have formed near local water level, at least for the period before approximately $2500 \mathrm{cal}$. yr BC. Therefore, the vertical error of $\pm 10 \mathrm{~cm}$ that we applied to the Almere data to account for the uncertainty in the relationship between local water level and the level of peat formation, was also applied to this data set. To avoid dating of old soil material, Roeleveld \& Gotjé often took their samples up to $14 \mathrm{~cm}$ above the sand-peat transition. To account for compaction after peat formation, the height of their error boxes was determined by an upward range of twice the distance between the sandpeat contact and the sample. We included this range in the error boxes, together with the sample thickness $(2-5 \mathrm{~cm})$ and the vertical errors related to the sampling method and altitude measurement that were assumed to be $\pm 5 \mathrm{~cm}$. With a height between 32 and 60 $\mathrm{cm}$, the resulting error boxes (Fig. 10) are considerably thicker than those depicted by Roeleveld \& Gotjé (1993).

\section{Curve C}

For the period after 4200 cal. yr BC, the error boxes plot largely below the MSL-curve that seems to describe water-level rise in the Almere area. The Schokland data show a clear trend. Roeleveld \& Gotjé (1993, pp. 76 and 80) considered boxes 7, 9 and 11 'too old' due to erroneous sampling of old soil materi- al. The relatively high position of boxes 15,16 and 17 was taken to reflect a temporary increase of the rate of local water-level rise due to impeded drainage. Analogous to curves $A$ and $B$ (Figs. 8 and 9), curve $C$ in Fig. 10 represents the lower limit of local water levels in the Schokland area, taking into account the $95.4 \%$ statistical confidence range in age and the uncertainty in altitude. Between 5000 and $4200 \mathrm{cal}$. yr BC, curve $\mathrm{A}$ and $\mathrm{C}$ are in close agreement (Fig. 11). Between 4200 and 3700 cal. yr BC, the difference between curve $B$ and $C$ rapidly increases, suggesting differences in water-level development between the Almere area and the Schokland area. Between 3700 and 2000 cal. yr BC, the difference between curve $\mathrm{B}$ and $\mathrm{C}$ remains more or less constant, with curve $C$ around 70 $\mathrm{cm}$ below curve B (Fig. 11).

\section{Discussion and conclusions}

Various explanations can be proposed for the discrepancy between curves B and C in Fig. 11. It is possible that the discrepancy is not real, since curve B is a tentative curve based on scarce data. It may also be that curves $\mathrm{B}$ and $\mathrm{C}$ represent different lower limits of an error band around the same regional water-level curve for the Flevo lagoon, i.e. they could represent local variations in error band width. Anyhow, one boundary condition must be satisfied: regional and local water levels in the Flevo lagoon can not have been below mean sea level. Taking Van de Plassche's (1982) MSLcurve as representative of mean sea level, the Almere data seem consistent with this requirement (Figs. 8 and 9). However, the Schokland error boxes covering the period after 4200 cal. yr BC (Fig. 10) are almost completely below the MSL-curve. Three hypothetical explanations for this will be discussed below. 

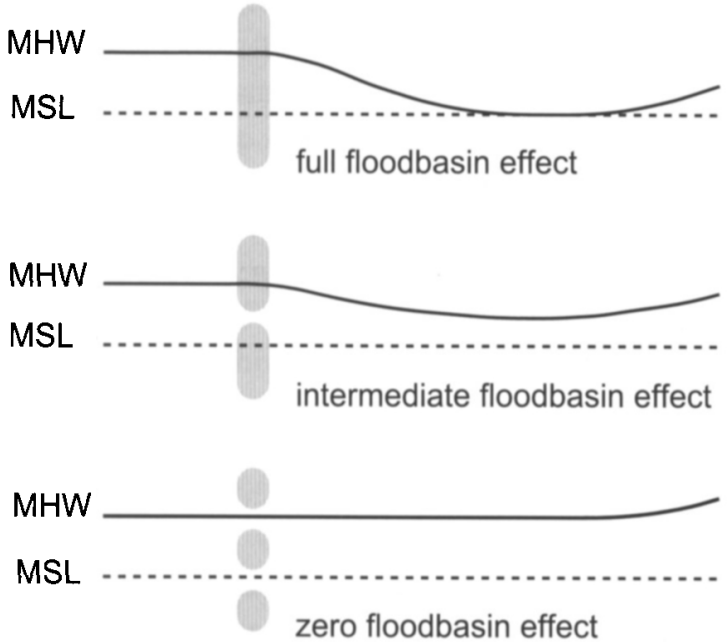

Fig. 12. Schematic representation of different amounts of tidal damping in a river-influenced back-barrier lagoon (after Van de Plassche, 1995b) (MHW = mean high water, $\mathrm{MSL}=$ mean sea level). The magnitude of the floodbasin effect is determined by the ratio between the volume of flood water that can enter through the tidal inlet and the storage volume of the back-barrier basin. A full floodbasin effect is likely to occur in a large basin with narrow inlets, while a zero floodbasin effect could characterize a small basin with wide inlets.

Hypothesis 1: MSL-curve indicates a level above mean sea level

In general, when tides are present, peat in a back-barrier lagoon is believed to develop near local mean high water level rather than near local mean water level (Jelgersma, 1961; Roeleveld, 1974; Van de Plassche, 1982, 1995a, 1995b; Van de Plassche \& Roep, 1989; Kiden, 1995). If this assumption is correct, than the Almere data, plotting around the MSLcurve, suggest absence of significant vertical tidal motion in the southern Flevo lagoon. However, presence of tides in this area seems likely, at least for the period before 4200 cal. yr BC.

Roep \& Beets (1988) reconstructed coastal tidal amplitudes of slightly greater than one metre for most of the period under study, based on dated sedimentary structures in the coastal barrier indicative of palaeotide levels. Reconstructions of Holocene coastal evolution show a relatively 'open' coast of Holland (Fig. 1) before 4200 cal. yr BC (Beets et al., 1992, 1994; Beets \& Van der Spek, 2000). Under these circumstances, the tidal wave is transmitted to the backbarrier lagoon through wide tidal inlets, with limited damping of the tidal amplitude (Fig. 12). If it is therefore assumed that that vertical tidal motion was present in the Almere area with peat formation around mean high water, this implies that the present MSLcurve in fact indicates a level above mean sea level.
A 'too high' MSL-curve was considered by Van de Plassche (1995b) as one of various options to explain the low position of the Schokland data. Lowering the MSL-curve in Fig. 10 by an arbitrary $0.5 \mathrm{~m}$ would result in a convergence with time of the Schokland data upon mean sea level. This convergence could be interpreted as development of a 'floodbasin effect' in the back-barrier lagoon (Fig. 12). The floodbasin effect involves back-barrier attenuation of the tidal amplitude as a tidal wave enters a large storage basin through a relatively narrow tidal inlet. An increasing floodbasin effect in the Flevo lagoon could have been caused by development of beach-barriers, and narrowing and closing of tidal inlets along the coast of Holland during the period from 4500 to $3500 \mathrm{yr} \mathrm{BC}$ (Beets et al., 1992, 1994; Beets \& Van der Spek, 2000). However, the Almere data, although incomplete for the period 4200-2000 cal. yr BC, show no indications of a comparable development of a floodbasin effect, casting some doubt on this explanation for the discrepancy between the Schokland data and the MSL-curve.

\section{Hypothesis 2: relative basin subsidence of the Schokland area}

The Flevo lagoon is located in the structural Zuiderzee Basin that has existed since the Miocene (Zagwijn, 1989, p. 113). Holocene rates of subsidence of this area are unknown. Van de Plassche (1995b) mentioned subsidence of the Flevo lagoon as a possible explanation for the discrepancy between the MSL-curve and Schokland data after 4200 cal. yr BC. Nevertheless, he still considered the available sea-level data base for The Netherlands inconclusive in this respect. Basin subsidence can have resulted in a lowering of the time-depth data from the Flevo lagoon with respect to the MSL-curve. If the timedepth data from the Flevo lagoon are restored to their hypothetical original position by raising them to a level at or above the MSL-curve, convergence with time of the Schokland data upon mean sea level, can be interpreted as development of a floodbasin effect in the back-barrier lagoon, like in hypothesis 1. Again, the apparent absence of a floodbasin effect in the data from the Almere area seems to contradict this interpretation. In theory, this problem can be solved by assuming significant subsidence of the Schokland area with respect to the Almere area. However, data on long-term subsidence since the Early Pleistocene (Van Montfrans, 1975) and recent movements determined by geodetic measurements over the last century (Lorentz et al., 1991) show that this option is unlikely. 


\section{Hypothesis 3: depth/time errors in the Schokland data}

A remarkable feature of the Schokland data is that particularly the error boxes representing sedge and reed-sedge peat samples plot significantly below the MSL-curve (Fig. 10). The error boxes of wood peat dates agree with the MSL-curve. As noted above, sedge peat may form several decimetres below the water table [down to $30 \mathrm{~cm}$ (Den Held et al., 1992)], whereas wood peat forms near local water level. This means that a change towards wetter conditions of peat formation accompanies the dip of the Schokland time-depth data relative to the MSL-curve, around 4200 cal. yr BC. Given this coincidence, the assumption of Roeleveld \& Gotjé (1993, p. 78) of peat formation around local water level may be questioned. An upward correction of $30 \mathrm{~cm}$ could largely bridge the gap with the MSL-curve. Recent investigations by Van de Plassche et al. (in prep.) at one of the Schokland sites (h in Fig. 2) suggest an additional source of error associated with the above-mentioned change in peat composition. Especially sedge and reed peat may contain numerous fine roots not easily identified and removed from bulk samples prior to dating. This may have caused a rejuvenation of the Schokland sedge and reed-sedge peat samples of the order of a few hundred years. These potential depth/time errors represent the simplest explanations that satisfy all the data from the Flevo lagoon presently available.

\section{Final remarks}

At present, none of the above presented explanations can be totally excluded and a combination of various explanations also may be valid. An important source of uncertainty is the scarcity of reliable basal peat time-depth data from the Almere area for the period after 4200 cal. yr BC. Naturally, more data from the Schokland area for the period after 4200 cal. yr BC could also help to find out whether the present data from this area record a local or a regional phenomenon.

A fundamental issue concerns the magnitude of the tidal amplitude in the Flevo lagoon and its evolution. The present basal peat data are especially ambiguous in this respect. A complicating factor is that considerable subregional differences in the level of peat formation seem to have existed [e.g. the altitudinal difference between the 'Hoge Vaart' error boxes $2 / 3$ through 7 (Fig. 9) and the error boxes 12 through 15 (Fig. 8) representing a location around $0.5 \mathrm{~km}$ north of the Hoge Vaart excavation pit]. The present data do not allow distinction between the effects of (1) differences in local tidal amplitude, (2) 'free' river gradient or (3) obstructed drainage of river or seepage water. An option that deserves further research is that significant tidal motion may have been absent in the most inland parts of the Atlantic Flevo lagoon (e.g. the Schokland area), despite a relatively open coast. This option is supported by historic data of very limited tidal motion around Schokland in the early 20 th century [tidal range $0.2 \mathrm{~m}$ (Dirkx et al., 1996, p. 9 and 35)], when there was a good connection between the Zuiderzee (the successor of the Flevo lagoon) and the North Sea.

Although they are incomplete and questions about their interpretation remain, the data presented in this paper presently form the best proxy on which models of palaeo-environmental and palaeogeographical evolution of the Flevo lagoon can be build. These in turn constitute a basis for the assessment of the archaeological potential of Flevoland.

\section{Acknowledgements}

This study was funded by the National Service for Archaeological Heritage (ROB), the DirectorateGeneral for Public Works and Water Management (Rijkswaterstaat, Directie IJsselmeergebied) and the Ministry of Agriculture, Nature Management and Fisheries. Ute Menke and Gerda Lenselink (RIZA, Lelystad) are thanked for supplying valuable borehole information revealing the morphology of the Pleistocene substratum. Barbara Duran is thanked for working out a draft of Fig.5. We are also indebted to Henk Berendsen (Faculty of Geographical Sciences, Utrecht University) and Henk Wolfert (Alterra, Wageningen University and Research Centre) for commenting on drafts of this paper, and to Patrick Hommel (Alterra, Wageningen University and Research Centre) for searching literature on hydrological conditions of peat formation. We appreciated the constructive comments of O. Van de Plassche, Tj.C.E. Van Weering, one anonymous reviewer and the journal editor C. Kasse.

\section{References}

Beets, D.J., Van der Valk, L. \& Stive, M.J.F., 1992. Holocene evolution of the coast of Holland. Marine Geology 103: 423-443.

Beets, D.J., Van der Spek, A.J.F. \& Van der Valk, L., 1994. Holocene ontwikkeling van de Nederlandse kust. RGD rapport 40.016 Projekt Kustgenese, Rijks Geologische Dienst (Haarlem): 53 pp.

Beets, D.J. \& Van der Spek, A.J.F., 2000. The Holocene evolution of the barrier and the back-barrier basins of Belgium and the Netherlands as a function of late Weichselian morphology, relative sea level rise and sediment supply. Geologie en Mijnbouw / Netherlands Journal of Geosciences 79: 3-16.

De Jong, A.F.H., 1981. Natural ${ }^{14} \mathrm{C}$ variations. Unpublished Ph.D. dissertation, Rijksuniversiteit Groningen (Groningen): 119 pp. 
Den Held, A.J., Schmitz, M. \& Van Wirdum, G., 1992. Types of terrestrializing fen vegetation in the Netherlands. In: Verhoeven, J.T.A. (ed.): Fens and bogs in the Netherlands: vegetation, history, nutrient dynamics and conservation. Geobotany 18: 237-321.

Dirkx, G.H.P., Hommel, P.W.F.M. \& Vervloet, J.A.J., 1996. Kampereiland: een wereld op de grens van zout en zoet. Matrijs (Utrecht): $112 \mathrm{pp}$.

Doppert, J.W.C., Ruegg, G.H.J., Van Staalduinen, C.J., Zagwijn W.H. \& Zandstra, J.G., 1975. Formaties van het Kwartair en Boven-Tertiair in Nederland. In: W.H. Zagwijn \& C.J. Van Staalduinen (eds.): Toelichting bij geologische overzichtskaarten van Nederland. Rijks Geologische Dienst (Haarlem): 11-56.

Ente, P.J., Koning, J. \& Koopstra, R., 1986. De bodem van Oostelijk Flevoland. Flevobericht 258, Rijksdienst voor de IJsselmeerpolders (Lelystad): $181 \mathrm{pp}$.

Gotjé, W., 2001. Bodemkunde en landschapsecologie III: vegetatieontwikkeling en diatomeeën. In: Hogestijn, J.W.H. \& Peeters, J.H.M. (eds.): De mesolithische en vroeg-neolithische vindplaats Hoge Vaart - A27 (Flevoland). Rapportage Archeologische Monumentenzorg 79, ROB, (Amersfoort): vol. 9.

Heidemii, 1993. Atlas: Pleistoceen zand in Zuidelijk Flevoland; Rivierduinen, dekzandruggen en verspoeld pleistocene zandlagen in de secties $\mathrm{Gz}, \mathrm{Kz}$, Lz en Nz van Zuideliik Flevoland. Rapportnummer 635/EA93/C326/21083, Heidemij Advies.

Hogestijn, J.W.H. \& Peeters, J.H.M. (eds.), 2001. De mesolithische en vroeg-neolithische vindplaats Hoge Vaart - A27 (Flevoland). Rapportage Archeologische Monumentenzorg 79, ROB (Amersfoort): 20 vols.

Jelgersma, S., 1961. Holocene sea level changes in The Netherlands. Mededelingen van de Geologische Stichting, Serie C VI 7: $100 \mathrm{pp}$.

Kiden, P., 1995. Holocene relative sea level change and crustal movement in the southwestern Netherlands. Marine Geology 124: $21-41$

Lorentz, G.K., Groenewoud, W., Schokking, F., Van den Berg, M.W., Wiersma, J., Brouwer, F.J.J. \& Jelgersma, S., 1991. Heden en verleden, Nederland naar beneden??? Interim-rapport over het onderzoek naar bodembeweging in Nederland. Rijkswaterstaat/Rijks Geologische Dienst (Delft/Haarlem/Rijswijk): 75 pp.

Louwe Kooijmans, L.P., 1974. The Rhine/Meuse delta; four studies on its prehistoric occupation and Holocene geology. Analecta Praehistoria Leidensia 7: $421 \mathrm{pp}$.

Makaske, B., Van Smeerdijk, D.G., Mulder, J.R. \& Spek, T., 2002a. De stijging van de waterspiegel nabij Almere in de periode 53002300 v. Chr. Alterra-rapport 478, Alterra (Wageningen): 105 pp.

Makaske, B., Van Smeerdijk, D.G., Kooistra, M.J., Haring, R.M.K., Verbauwen, E.C. \& Smit, A., 2002b. Een verkenning van begraven dekzandbodems in een bodembeschermingsgebied ten zuidoosten van Almere; een interdisciplinair onderzoek naar de kwaliteit van het bodemarchief, met implicaties voor archeologische waarden. Alterra-rapport 486, Alterra (Wageningen): $147 \mathrm{pp}$.

Menke, U., Van de Laar, E. \& Lenselink, G., 1998. De geologie en bodem van Zuidelijk Flevoland. Flevobericht 415, Rijkswaterstaat Directie IJsselmeergebied (Lelystad): $93 \mathrm{pp}$.

Mook, W.G. \& Streurman, H.J., 1983. Physical and chemical aspects of radiocarbon dating. In: Mook, W.G. \& Waterbolk, H.T. (eds): Proceedings of the first international symposium ${ }^{14} \mathrm{C}$ and archeology, Groningen, 1981. PACT 8: 31-55.

Peeters, H., Makaske, B., Mulder, J., Otte-Klomp, A., Van Smeerdijk, D., Smit, S. \& Spek, T., 2002. Elements for archaeological heritage management: exploring the archaeological potential of drowned Mesolithic and Early Neolithic landscapes in Zuidelijk Flevoland. Berichten van de Rijksdienst voor het Oudheidkundig Bodemonderzoek 45: 83-125.
Roeleveld, W., 1974. The Holocene evolution of the Groningen marine-clay district. Berichten van de Rijksdienst voor het Oudheidkundig Bodemonderzoek 24, Supplement: $132 \mathrm{pp}$.

Roeleveld, W. \& Gotjé, W., 1993. Holocene waterspiegelontwikkeling in de Noordoostpolder in relatie tot zeespiegelbeweging en kustontwikkeling. In: Gotjé, W.: De Holocene laagveenontwikkeling in de randzone van de Nederlandse kustvlakte (Noordoostpolder), Unpublished $\mathrm{Ph} . \mathrm{D}$. dissertation, Vrije Universiteit (Amsterdam): 76-86.

Roep, T.B. \& Beets, D.J., 1988. Sea level rise and paleotidal levels from sedimentary structures in the coastal barriers in the western Netherlands since 5600 BP. Geologie en Mijnbouw 67: 5360.

Spek, T., Bisdom, E.B.A. \& Van Smeerdijk, D.G., 1997. Verdronken dekzandgronden in Zuidelijk Flevoland (archeologische opgraving 'A27-Hoge Vaart'): een interdisciplinaire studie naar de veranderingen van bodem en landschap in het Mesolithicum en Vroeg-Neolithicum. Rapport 472.1, DLO - Staring Centrum (Wageningen): $187 \mathrm{pp}$. (has also appeared as volume 7 in Hogestijn \& Peeters, 2001).

Spek, T., Bisdom, E.B.A. \& Van Smeerdijk, D.G., 1999. Verdronken dekzandgronden in Zuidelijk Flevoland (archeologische opgraving 'A27-Hoge Vaart'): een aanvullend bodemkundig en palaeoecologisch onderzoek naar de landschapsvormende processen tijdens de laatste fase van bewoning (Vroeg-Neolithicum). Rapport 472.2, DLO - Staring Centrum (Wageningen): $154 \mathrm{pp}$. (has also appeared as volume 8 in Hogestijn \& Peeters, 2001).

Törnqvist, T.E. \& Bierkens, M.P.F., 1994. How smooth should curves be for calibration of radiocarbon ages? Radiocarbon 36 : 11-26.

Törnqvist, T.E., De Jong, A.F.M., Oosterbaan, W.A. \& Van der Borg, K., 1992. Accurate dating of organic deposits by AMS ${ }^{14} \mathrm{C}$ measurement of macrofossils. Radiocarbon 34: 566-577.

Törnqvist, T.E., Van Ree, M.H.M., Van 't Veer, R. \& Van Geel, B., 1998. Improving methodology for high-resolution reconstruction of sea level rise and neotectonics by paleoecological analysis and AMS ${ }^{14} \mathrm{C}$-dating of basal peats. Quaternary Research 49: 7285.

Van de Plassche, O., 1982. Sea level change and water-level movements in the Netherlands during the Holocene. Mededelingen Rijks Geologische Dienst 36-1: 93 pp.

Van de Plassche, O., 1995a. Periodic clay deposition in a fringing peat swamp in the lower Rhine-Meuse river area, 5,400-3,400 cal BC. Journal of Coastal Research Special Issue 17: 95-102.

Van de Plassche, O., 1995b. Evolution of the intra-coastal tidal range in the Rhine-Meuse delta and Flevo lagoon, 5700-3000 yrs cal B.C. Marine Geology 124: 113-128.

Van de Plassche, O. \& Roep, T.B., 1989. Sea level changes in the Netherlands during the last 6500 years: basal peat vs. coastal barrier data. In: Scott, D.B., Pirazolli, P.A. \& Honig, C.A. (eds): Late Quaternary sea level correlation and applications. NATO ASI Series C256, Kluwer (Dordrecht): 41-56.

Van de Plassche, O., Bohncke, S.J.P. \& Makaske, B., in prep. Relative sea-level change in the central Netherlands (7200-3500 cal $\mathrm{BP})$ : implications for crustal stability and local tidal range. (preliminary title) Quaternary International.

Van der Plicht, J., 1993. The Groningen radiocarbon calibration program. Radiocarbon 35: 231-237.

Van Dijk, G.J., Berendsen, H.J.A. \& Roeleveld, W., 1991. Holocene water level development in The Netherlands' river area; implications for sea level reconstruction. Geologie en Mijnbouw 70: 311-326.

Van Montfrans, H.M., 1975. Toelichting bij de ondiepe breukenkaart met diepteligging van de Formatie van Maassluis. In: Zagwijn, W.H. \& C.J. Van Staalduinen (eds.): Toelichting bij 
geologische overzichtskaarten van Nederland. Rijks Geologische Dienst (Haarlem): 103-108.

Van Smeerdijk, D.G., 1989. Alder car, growth and drowning in the IJsselmeer region, an aspect of Dutch coastal development, Acta Botanica Neerlandica 38: 477-491.
Zagwijn, W.H., 1986. Nederland in het Holoceen. Rijks Geologische Dienst (Haarlem): 46 pp.

Zagwijn, W.H., 1989. The Netherlands during the Tertiary and the Quarternary: a case history of coastal lowland evolution. Geologie en Mijnbouw 68: 107-120. 